\title{
Introduction
}

\section{Why Does the Past Matter?}

\section{Colin Divall, Julian Hine and Colin Pooley}

In our everyday lives we are all constantly learning from past experiences. Although we may not consciously recognise the fact, many everyday actions that we take and behaviours that we exhibit are shaped by previous experiences. This is true for the most significant aspects of most people's lives, for instance in personal relationships or at work, but also for the apparently more mundane aspects such as the choice of route or transport mode used for a journey. If one choice proves problematic we are likely to make adjustments and choose, where possible, to adjust travel plans. Where no alternatives are available we are likely to become frustrated at the lack of choice available, and by our inability to turn those things we have learned from previous experiences into practice in our everyday lives. Given that at this level learning from the past is so ubiquitous it is perhaps surprising that an understanding of past processes and experiences do not more fully inform present-day policy making at either national or local levels. This is certainly the case for most transport policy (the focus of this volume) where, as in most other areas of policy making, decisions tend to be taken on the basis of short-term political or practical (usually financial) expediency. We are not arguing that history repeats itself, or that every contemporary transport dilemma has an historical counterpart: but we are suggesting that in many contexts of transport planning a better understanding of the context and consequences of past decisions and processes could lead to more effective policy decisions. This requires not only that those who make these decisions are aware of, and learn from, past events; but also that historians analyse and present the past in a way that is useful for the present. The essays in this volume collectively explore and demonstrate these points across a wide range of transport modes and contexts. 
There are a number of reasons why an understanding of the past is particularly relevant to the development of contemporary transport policy. First, the transport technologies that we use today have been remarkably persistent. All have been available for more than a century and despite massive technological refinements and improvements they have remained fundamentally the same. Thus a modern train or car would be instantly recognisable to a traveller from a century ago as essentially the same form of transport, providing a similar service and placing similar demands on the environment. Certainly most forms of transport have become more widely available, and volume of use has increased massively for the more expensive and environmentally damaging forms of transport (most notably for motor vehicles and air travel), while less environmentally demanding modes such as walking and cycling have declined in importance; but in essence we still have much the same transport options as we did a century ago. (Dyos and Aldcroft 1969; Freeman and Aldcroft 1988; Knowles et. al. 2008; Shaw and Docherty 2014)

Second, the role of transport and travel in our everyday lives has also changed little over the past century and more. Although the availability, affordability and speed of much modern transport has broadened horizons and enabled more people to travel further, faster and more often, the fundamental importance of mobility to people's lives has not in essence changed. The need to travel for work, education, shopping, socialisation, pleasure and leisure was as central to everyday life a century ago as it is today. Journeys may have been slower and in some cases shorter, though even in the twenty-first century most everyday travel is over relatively short distances and in urban areas travel speeds are not necessarily significantly faster, but the rhythms of daily life for most people, and the significance of transport and travel to those routines, has remained largely unchanged. (Pooley et al. 2005, 2006) 
Third, the impact of past transport infrastructure continues to have a major impact on how we travel and on our everyday travel experiences. Most of the rail routes that exist today were originally constructed at least a century and a half ago; and, especially in urban areas, long-standing road patterns continue to exert a major influence over present-day planning decisions. For instance, the problems of managing modern traffic in any urban area such as York, Chester or Ludlow with a mediaeval street plan and many historic buildings are all too obvious. (Larkham 2002) Even with air transport a decision in 1930 to build an airfield on the present site of Heathrow continues to influence debates about how the demand for air transport in southern England should be managed. (Heathrow airport website: History). Physical presences from the past continue to influence and shape many aspects of travel and transport today.

Fourth, and related to the above point, transport is to a large degree subject to considerable inertia or 'path dependency'. (Arthur 1994). Because of high infrastructure costs, the power of large companies that provide fuel and transport, and the persistent travelling habits of the population, the ways in which we travel have been remarkably slow to change. Once the car was perceived and established as the most desirable form of personal private transport in the early years of the twentieth century in Britain (and long before most households had access to a car), the dominance of the internal-combustion engine was secured. The marketing strategies and political power of major motor manufacturers and petroleum companies helped to create an environment in which the position of the car in the transport system was not seriously challenged with, for instance, the reshaping of cities to suit cars and to the detriment of other forms of transport. In this way systems of automobility became firmly established as a path-dependent process. (Sheller and Urry 2000; Urry 2004; Featherstone et. al. 2005; Conley 2009). 
Counterfactual history is not especially fashionable or well-regarded by many historians (Hawthorne 1991; Ferguson 2003; Bunzl 2004; Evans 2014) but there can sometimes be merit in considering how things might have been different had an alternative path been taken. From such analysis it might be possible to learn lessons for the future. For instance what role would rail transport have played in the British transport system today if the line closures recommended by the Beeching Report (1963) had not taken place (McKie 2013), and how might everyday travel be different in the twenty-first century had the development of the automobile been restricted in Britain in the early-twentieth century (Pooley 2010)? In one sense what are being considered in such scenarios are simple opportunity costs: all too often in transport planning and development one path is followed (usually for political or financial reasons) without due consideration being given to other possibilities. Potentially a similar situation is occurring today with the development of the HS2 rail link from London to Birmingham and, eventually, to northern England. As Divall shows in Chapter 6, more effective and more socially equitable improvements in transport in Britain could probably be achieved if the money committed to HS2 was spent differently. We believe that there is a powerful argument for planners and policy makers to be at least aware of relevant transport history when proposing new schemes: and for historians to strive to make an understanding of the past available and accessible to planners and policy makers. The essays in this book seek to provide such understanding across a range of transport modes and time periods, chiefly in relation to the United Kingdom.

\section{Where Are We Now?}

Arguing that the past can provide important information relevant to the present is, of course, not new although it has been rarely applied in the field of transport policy. The well-known phrase that the past is the key to the present is usually attributed to Kenneth M. Stampp, writing about US slavery in 1956, but it can clearly be applied much more widely and most 
probably has older antecedents. Since the early 2000s a group of academic historians has sought to promote an understanding of relevant issues from the past to policy makers and planners via the History and Policy network. Its on-line forum freely publishes historical research that is relevant to policy makers, journalists and others concerned with a range of contemporary issues, and historians lead workshops and seminars within Whitehall with the goal of enhancing civil servants' appreciation of the relevance of the past. (Thane 2009; History and Policy website (a)). These services have received considerable praise from users but, so far, there is limited coverage of transport issues with one policy paper by Duncan Needham (2014) on the history of the debate about London's third airport, and a short opinion piece by Colin Divall (2010) on expansion of the rail network the most prominent items. Interestingly transport does not currently appear as a separate theme in the site's listing of research papers, despite its obvious centrality to British economy and society and the controversial nature of many transport-related policy decisions. Divall has also argued elsewhere for an historical perspective to transport policy (Divall 2011, 2012, 2015; Merriman et al 2013), and in 2014-15 he co-facilitated several workshops within Whitehall on behalf of History and Policy. But for the most part transport historians and transport policy makers have trod separate paths. The focus of the recent Research Excellence Framework 2014 (REF) on the 'impact' that research by British academics has had may serve to focus more research in this direction (REF website), but in transport studies there remains a long way to go.

Policy makers and politicians are certainly not totally unaware of the significance of a historical perspective: as the British Labour Party MP Frank Field states on the History and Policy website 'History has a huge amount to teach us about how we got to where we are and how we might move forward'. (History and Policy website (b)) Some recent academic research has also achieved substantial publicity and has generated real debate among 
politicians and policy makers. Examples include Thomas Piketty's (2014) long-run economic analysis and critique of global capitalism and inequality, and Richard Wilkinson's and Kate Pickett's (2009) analysis of why more equal societies do better on almost all measures of social and economic health. Furthermore Jo Guldi and David Armitage have recently published their History Manifesto (2014) which arose from discussion (mainly in the USA) about the future of history and the role of academics in public culture. However, while William Hague (himself a published historian) employed full-time historians at the British Government's Foreign and Commonwealth Office to provide a long-term perspective on international issues during his term office as Secretary of State for Foreign and Commonwealth Affairs (2010-14) (Armitage 2014) there is little evidence of this practice being more widely adopted by British government ministers. Those who can reflect on their own past experiences, and bring them to bear on present-day issues, often have more regard for the value of the past. For instance Jonathan Powell, Downing Street Chief of Staff under Prime Minister Tony Blair from 1995 to 2007, and also the chief British negotiator on Northern Ireland during the peace talks that led to the Good Friday Agreement (1998), has brought these experiences of conflict resolution to his more recent writings on dealing with the threat of terrorism, and to his role as CEO of the charity Inter-Mediate that works on the resolution of armed conflicts. Based on his experiences in Northern Ireland he argues strongly that military solutions to terrorist threats are not possible, and that only negotiations can lead to successful resolutions. (Powell 2014a, 2014b)

Some countries do appear to have more regard for the power of historical understanding in transport policy making, as shown in Chapter 1 where Bert Toussaint examines the role that historians play within the Dutch ministry of infrastructure and environment. Although the individual case studies that follow are all concerned with the British Isles, this international theme is important for the future health of the relationship 
between history and policy in the UK: we argue strongly that it is incumbent on both historians and policy makers to learn from experiences elsewhere. In the policy area of transport and mobility the stakes are high. High levels of mobility are central to the success of all economies and societies, but this mobility has severe costs in terms of resource use, pollution (both local and global), congestion and human health. (Banister 2005, 2007). Given that societies have been grappling with problems of transport and mobility for centuries, and that the basic parameters and components of everyday travel have changed relatively little over more than a century, it seems obvious that there is potential to learn lessons from the past in the development of present-day transport policy.

\section{The Scope and Aims of the Volume}

It is first necessary to define the terminology used in this volume (and in the title) and to delimit the scope of the book. By transport we are not referring only to the physical infrastructure of roads, rails, airports and so on, along with the motor vehicles, trains and planes that use these structures, but also to the wider concept of mobility: the ability of people to move freely and easily in ways that enable them to undertake their daily life of work, education, leisure and pleasure. Most everyday travel in Britain is over short distances: in 201318 per cent of all trips were under one mile and 67 per cent under five miles in distance. Only five percent were more than 25 miles. (DfT 2014). For most people, most of the time, what is important to them is how the transport system works and enables their mobility within a relatively circumscribed locality. We argue that this has changed little over time. (Pooley et. al. 2005) Moreover despite the obvious increase in car use over the twentieth century, a significant proportion of all journeys are still undertaken on foot. Walking accounted for 22 per cent of all trips undertaken in 2013, second only to travel by car as a driver or passenger (64 per cent), and substantially greater than travel by bus (seven per cent) and train (three per cent). Seventy eight per cent of all trips less than one mile were 
on foot. (DfT 2014). A century ago walking was the dominant form of transport, and although it has declined it remains a crucial element of most people's everyday travel experience, despite being barely recognised as a mode of transport in many policy documents and receiving less investment even than cycling (which accounts for fewer than two per cent of all trips), let alone road and rail infrastructure. Essays in this volume range across almost the whole spectrum of transport and travel experiences in Britain. Of course transport is important not only for personal mobility but also for the movement of freight from one location to another. Increasing consumer demand for an ever wider range of goods places significant demands on both the road and rail networks that are used for distribution. (Roth and Divall 2015) While recognising the importance of freight transport the essays in this volume focus principally on passenger transport and the mobility of people. Likewise we do not deal explicitly with the important and increasing role of the internet and social media in enabling virtual mobility, focusing instead on physical movement from place to place.

We should also define what we mean by policy. Our understanding is a broad one encompassing both national and local policy making. We recognise that although there may be a national policy framework (for instance DfT/DoH 2010; DfT 2011) the decisions that most affect people's lives and the ways in which they travel are taken at the local level. It is important to consider how national guidelines are interpreted and implemented, and to recognise that not every ministerial policy statement is translated into action. There can often be a large gap between what is in a policy document and what actually occurs on the ground. (Vigar 2002) It should also be recognised that many of the forces influencing the delivery and development of transport are not directly related to transport policies at all. For instance economic policies adopted by a national government may have a significant effect in, say, limiting funds during periods of financial austerity and thus frustrating attempts by local government to provide or improve transport. Furthermore while some such effects can be 
predicted, central government policies may sometimes have unintended consequences that can influence transport provision and everyday mobility. It is also important to recognise that individuals also develop their own views, or policies, on how they should travel. Although influenced to some extent by government (national or local) statements on policy, and by media coverage of such statements, in practice most everyday travel decisions are based on a personal evaluation of what will work, and can be afforded, by an individual or family. In this sense policy making interacts with individual decision making and, arguably, through the ballot box individual choices and preferences can feed back to shape local and national government policies. For instance the dominance of car use for everyday transport makes policy makers very reluctant to restrict, or financially penalise, drivers, even though such policies may follow logically from national statements about the need to develop more sustainable transport systems.

Learning lessons from the past (the sub-title of this volume) is a bold statement and also requires some further explanation. None of the essays in this volume argues that history repeats itself, or that conditions today are identical to those decades ago. However we are collectively suggesting that it is foolish to completely ignore what has gone before. While the recent past may appear at first sight to be most relevant, as stated above most forms of transport used today as well as the types of mobility that are most important on an everyday basis have been present for a century or more, and thus a longer time perspective can also be valuable. Part of the lesson to be learned may be to recognise the ways in which past practices can be adapted to suit contemporary society and transport needs. One difficulty of producing and presenting transport and mobility history in a form that is useful to planners and policy makers lies in the sources that are available. Statistics are rarely constant over time (for instance even definitions used in the National Travel Survey have changed, making direct comparisons difficult) and other sources can be much more problematic. All policy 
statements must be read within the context of the political climate and complexion of the time; and it is hard to gather reliable accounts of individual travel experiences beyond the recent past. Although oral testimonies gathered today may go back to the mid-twentieth century they inevitably become less robust the more distant they are from the present. Sources used by each author are discussed in individual essays and an appendix to the volume also attempts to provide some guidance on key sources relevant to transport history and policy.

\section{The Individual Essays}

As already mentioned, following this introduction further context is provided by Bert Toussaint, who draws on his experience in the Rijkswaterstaat, the ministerial agency for water management and infrastructure in the Netherlands, to discuss the development and use of history-learning concepts and tools as applied to transport projects. He distinguishes two aspects of history learning: contextual learning and behavioural learning. Contextual learning focuses on gaining insight into broader temporal processes of policy making; behavioural learning aims at changing professional attitudes by applying historical knowledge and insights in policy-making trajectories and implementation projects. Contextual learning sessions in transport-history projects have included workshops, where research results were discussed with policy makers, strategic advisors and project managers; behavioural learning is still in its infancy, but a transport-policy decision-simulation project is being developed and tested. It is argued that the Dutch experience demonstrates the value of both developing clear conceptual tools for the use of historical knowledge in transport planning, and of applying these history-learning concepts to specific transport projects.

The remainder of the book is divided into two sections. The first contains six essays focussing on different aspects of travel from the perspective of social justice and mobility identities. By examining a wide range of different travel modes these chapters discuss the 
ways in which some travellers can become marginalised within the transport system, with restricted mobility that fundamentally affects the quality of their everyday lives. The second section (three essays) examines the ways in which transport and mobility are marketed, and the role of marketing strategies in shaping the ways in which we travel.

Frances Hodgson's focus, in Chapter 2, is on gender and walking in the urban environment. She carefully develops an understanding of the patterns of disadvantage and social justice that particularly affect female pedestrians through a historical gendered analysis of women's walking and women's resistances. It is argued that the historical patterns of statutory underinvestment in walking provision, and neglect of gender in transport policy, result in gendered patterns of temporal and spatial exclusion. The analysis presented draws on two separate community studies conducted in 1984 and 2007 from one inner-city neighbourhood, together with archived visual evidence, to build a layered account of walking strategies and resistances to exclusion. Analysis of women's own accounts of walking provides evidence of women using competencies and strategies to stay safe, and evidence of women's individual and collective resistance to disadvantage through history. In remembering, documenting and archiving social practice of women in this neglected area this paper contributes to a usable social history for transport planning and for women skilling, individually and collectively to resist spatial and temporal patterns of exclusion. This focus on gender and walking is particularly salient as women are still less likely than men to have regular access to car transport, and are more likely than men to be pedestrians for some of their journeys. (Pooley et al. 2013) In Chapter 3 Colin Pooley examines the tensions that arise between principles of social justice and environmental justice in transport and mobility and, especially, the contention that principles of social justice and environmental justice are often incompatible when applied to contemporary transport and mobility. For instance, restrictions on car use that would meet principles of environmental sustainability may unduly penalise 
some of the most disadvantaged members of society. Drawing on a range of recent research by the author, and focusing especially on trams and bicycles as key forms of everyday transport, the essay demonstrates that at certain periods in the past social and environmental justice in transport were more closely aligned than they are today, and that better understanding of past mobility may help to achieve more socially and environmentally equitable transport systems in the future.

Everyday travel in rural areas can be especially problematic, especially for those without access to a car. In Chapter 4 Aoife Ahern and Julian Hine examine this problem by focusing on the travel experiences of older people in rural areas across Ireland. The aim of the study was to discover what challenges, if any, face older people when trying to travel in rural areas and to examine if older people have unmet transport needs as a result of living in rural areas. They argue that older people in rural areas do have unmet transport needs, generally arising due to poor provision of alternatives to the car. Trips are difficult to make without a car and both social/recreational and health trips are among the most problematic for older people. The chapter focuses particularly on the difficulties faced by this generation of older people in adjusting to life without a car in rural areas. Using focus groups it was shown that this generation of older people, who are the first Irish generation to have experienced widespread car ownership and car use, are very car dependent, and find the adjustment from a motorised life to a car-less life very difficult. While the focus of the original study was not the interaction of history and transport policy, the findings are of relevance for policy makers. This older generation represent a watershed moment: they are the first generation to grow up with expectations of car ownership, and so recording their experiences of travel as they approach an age when car use becomes more difficult, or in some situations impossible, is important. In addition future generations will be even more car dependent, so understanding 
and recording the challenges faced by older people in rural areas today will help in creating a better transport policy for our ageing, car-dependent society.

Chapters 5 and 6 both focus on different aspects of rail travel. Arguably, this is one of the most fruitful areas for making links between the past and the present as the British railway network has been well-established for more than a century and a half, and the number of people travelling by rail has increased significantly in recent years. Hiroki Shin provides an historical overview of Britain's railway passenger representation up to 1947. He explores the emergence of passengers' collective interests in the late-nineteenth century, and examines how the subsequent development of the situation surrounding passenger issues in the earlytwentieth century consolidated a specific configuration of passenger representation, without paying much attention to the travelling public. The historical configuration of passenger interests affected the ways in which transport users' consultative bodies were formed in postwar Britain. By viewing voluntary passenger movements as a legitimate part of passenger transport, the chapter sheds light on the potentially significant role that a passengerrepresentation policy could play in balancing transport justice and the passenger business. In contrast, Colin Divall focuses on one of the most recent developments in British rail transport (HS2), and shows how the project to develop a high-speed rail link from London to Birmingham and then to northern England might be repeating mistakes of the past. In the nineteenth century, and to the detriment of rail travellers, politicians failed to insist on a strategic plan for the development of the country's railway network: much the same situation exists today. The arguments in favour of HS2, based upon the promise of economic growth and regional development, are grounded partly on a combination of apparently wilful ignorance or on the selective reading of the now half-century experience of high-speed railways across the globe. Furthermore history warns that the kinds of long-term projections of the need for future capacity on Britain's trunk railways being used to justify HS2 are likely 
to be subject to much greater levels of uncertainty than is being assumed. In sum the project bears all the hallmarks of the kinds of prestigious infrastructure projects that Bent Flyvbjerg et al. (2003) argue rich countries can afford to build, but that do not contribute much to the sum of economic well-being let alone social equity or ecological sustainability.

The final chapter in this section focuses on the human cost of our love affair with the car and, especially, on the halting history of attempts to develop effective control of drink driving in the UK. Bill Luckin carefully traces developments between two key moments in the history of drink-driving control in Britain, Barbara Castle's Road Safety Act in 1967 and Norman Fowler's lesser known Transport Act in 1981. The 1960s witnessed cumulative legislative activity, culminating in the introduction of the breathalyser test. This was followed by a period of confusion and inertia. In 1976 the Blennerhassett Report confirmed that Castle's measure had lost its cutting-edge and that further reform would be urgently needed. The chapter explains why successive governments stalled, compromised and succumbed to electoral and pro-motorist libertarian pressure. A concluding section suggests that a usable past in this area will only come more fully into focus when greater scholarly attention has been devoted to a crucial and still marginalised aspect of twentieth century social, political, cultural and mobility history: death and serious injury on the road. Although road casualties in Britain have fallen and are now among the lowest in any developed country, it can be argued that in almost any other arena the number of deaths and serious injuries linked to car use would have led to much more draconian intervention. The fact that death and injury on the roads goes largely unnoticed and unreported, apart from a few major incidents, emphasises the degree to which motoring has attained a dominant and almost unchallenged position within the British transport system.

In the twenty-first century many of our everyday decisions are affected by the marketing and advertising with which we are bombarded by a wide range of different media. 
This is just as true of how we travel as it is of what brand of coffee we choose to buy. The three essays in the second section all explore the role of marketing in shaping the mobility choices and decisions of the British travelling public. In Chapter 8 Nicola Forsdyke explores how history is relevant to contemporary transport and marketing practitioners. In particular she considers whether and how knowledge from the past is applied in day-to-day practice. Issues are explored from the practitioner's standpoint with particular reference to how marketing and branding theories can and have been used to deliver modal shift in urban transport. The theoretical context - how contemporary business marketing and branding theory can be applied to a transport context to deliver modal shift - is first examined. Case studies are then brought in to demonstrate whether historical evidence can show if and how theory has worked in practice. This theme is further developed in Chapter 9 by Martin Higginson who explores approaches to influencing modal share in markets where overall growth is not the providers' primary concern, such as 'captive' commuter markets. It considers the challenges faced by transport professionals, policy-makers, academics and historians seeking to understand the past; and asks what historical processes might be relevant to the present. Demand is shown to result from a combination of commercial efforts by providers and governments to expand markets, and external influences such as changes in populations, demographics and economic geography: phenomena that are at the heart of the debate on 'predict and provide' versus demand management in transport investment. Specific regard is paid to individual modes of transport and to markets in which a particular mode is under threat from competition, such as where established modes are being overtaken by new arrivals in the market place. The history of how marketing and branding shape and respond to public opinion is examined to help explain why demand for personal mobility has reached today's levels and forms. Finally in this section Peter Lyth focuses on air travel. Although for most people travel by plane still cannot be considered everyday transport, air travel is one of 
the fastest growing transport sectors with significant environmental and infrastructural implications. The chapter looks at the state of British civil aviation in the second decade of the twenty-first century, in an age of serious concern about man-made climate change and asks the question: why do we fly so much? It considers the marketing of leisure flying tourism - in the short-haul market of low-cost, 'no-frills' airlines like Ryanair and EasyJet, and asks to what extent that marketing effort has created a brand out of 'aeromobility', itself, a marker of a troubled prosperity and uncertain identity in a postmodern consumer society. It can be argued that the role of marketing practitioners in shaping travel behaviour often goes unnoticed, and these three chapters focus attention on one of the more hidden forces influencing mobility in the UK.

The issues raised by the chapters suggest that future research should attempt to place transport and mobility in Britain within a wider European and global context. We suggest that there are distinctive and deeply embedded characteristics of the history of mobility in Britain that inhibit the development of more environmentally sustainable forms of everyday travel, but that better understanding of these path-dependent historical processes could usefully inform current transport policies. As shown in Chapter 1 some countries and institutions do take the past more seriously than is common in Britain, and we suggest that there is definitely scope to learn from experiences elsewhere. The essays in this volume are, necessarily, selective in their approach and there are many other areas of transport and mobility where insightful links could be made between the past and the present. Of course, the past is not directly relevant to all present-day policy, but we argue that in many cases it is. Our hope in producing this set of essays is that policy makers will begin to pay greater attention to the lessons of history, and that historians will seek to present their data and analyses in forms that policy makers can engage with, thus going some way towards producing a more usable past. 


\section{References}

Armitage, D. (2014). Why politicians need historians. Guardian, 7 October.

http://www.theguardian.com/education/2014/oct/07/why-politicians-need-historians

(accessed 10 May 2015).

Arthur, W. (1994). Increasing Returns and Path Dependence in the Economy. Ann Arbor MI:

University of Michigan Press.

Banister, D. (2005). Unsustainable Transport: City Transport in the New Century. London:

Routledge.

Banister, D. (2007). The sustainable mobility paradigm. Transport Policy 15, pp.73-80.

Beeching, R. (1963). The Reshaping of British Railways. 2 vols. London: HMSO.

Bunzl, M. (2004). Forum essay - counterfactual history: a user's guide. The American Historical Review 109, pp.845-58.

Conley, J., ed. (2009). Car Troubles: Critical Studies of Automobility and Auto-mobility. Aldershot: Ashgate.

Department for Transport (DfT) (2011). Creating Growth, Cutting Carbon. Making Sustainable Local Transport Happen. London: HMSO.

Department for Transport (DfT) (2014). National Travel Survey 2013. London: DfT: https://www.gov.uk/government/statistics/national-travel-survey-2013 (accessed 10 May 2015).

Department for Transport (DfT) and Department of Health (DoH) (2010). Active Travel Strategy. London: HMSO

Divall, C. (2010). A return to Victorian levels of railway building? http://www.historyandpolicy.org/opinion-articles/category/colin-divall (accessed 10 May 2015). 
Divall, C. (2011). Transport History, the Usable Past and the Future of Mobility. In

Mobilities: New Perspectives on Transport and Society, ed. M. Grieco and J. Urry. Farnham: Ashgate, pp.305-19.

Divall, C. (2012). Business history, global networks and the future of mobility. Business History 54, pp.542-55.

Divall, C. (2015). Introduction: Cultural Histories of Sociabilities, Spaces and Mobilities. In Cultural Histories of Sociabilities, Spaces and Mobilities, ed. C. Divall. London: Pickering and Chatto, pp.3-16.

Dyos, H, J. and Aldcroft, D. (1969). British Transport: An Economic Survey from the Seventeenth Century to the Twentieth. Leicester: Leicester University Press.

Evans, R. (2014). Altered Pasts: Counterfactuals in History. London: Little Brown. Featherstone, M., Thrift, N. and Urry, J. (2005). Automobilities. London: Sage. Ferguson, N. ed. (2003). Virtual History: Alternatives and Counterfactuals. London: Basic Books.

Flyvbjerg, B., Bruzelius, N. and Rothengatter, W. (2003). Megaprojects and Risk: An Anatomy of Ambition. Cambridge: Cambridge University Press.

Freeman, M. and Aldcroft, D., eds. (1988). Transport in Victorian Britain. Manchester: Manchester University Press.

Guldi, J. and Armitage, D. (2014). The History Manifesto. Cambridge: Cambridge University Press.

Hawthorne, G. (1991). Plausible Worlds: Possibility and Understanding in History and the Social Sciences. Cambridge: Cambridge University Press.

Knowles, R., Shaw, J. and Docherty, I. (2008) Transport Geographies: Mobilities, Flows and Spaces. Oxford: Blackwell.

Larkham, P. (2002). Conservation and the City. London: Routledge. 
McKie, R. (2013). How Britain got it wrong about Britain's railways. Guardian, 2 March. http://www.theguardian.com/uk/2013/mar/02/beeching-wrong-about-britains-railways (accessed 10 May 2015).

Merriman, P., Jones, R., Cresswell, T., Divall, C., Mom, G., Sheller, M. and Urry. J. (2013). Mobility: geographies, histories, sociologies. Transfers 3, pp.147-65.

Needham, D. (2014) Maplin: the Treasury and London's third airport in the 1970s. History and Policy website: http://www.historyandpolicy.org/policy-papers/papers/maplin-the-

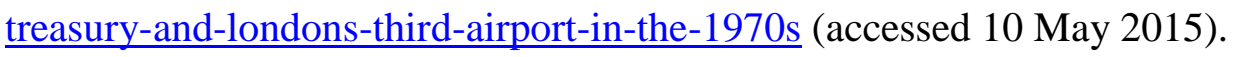

Piketty, T. (2014). Capital in the Twenty-First Century, trans. A. Goldhammer. Cambridge MA: Belknap Press.

Pooley C. (2010). Landscapes without the car: a counterfactual historical geography of twentieth-century Britain. Journal of Historical Geography 36, pp.266-75.

Pooley, C. with Jones, T., Tight, M. Horton, D., Scheldeman, G., Mullen, C., Jopson, A. and Strano, E. (2013). Promoting Walking and Cycling: New Perspectives on Sustainable Travel. Bristol: Policy Press.

Pooley, C., Turnbull, J. and Adams, M. (2005). A Mobile Century? Changes in Everyday Mobility in Britain in the Twentieth Century. Aldershot: Ashgate.

Pooley, C., Turnbull, J. and Adams, M. (2006). The impact of new transport technologies on intra-urban mobility: a view from the past. Environment and Planning A 38, pp.253-7. Powell, J. (2014a). How to talk to terrorists. Guardian 7 October. http://www.theguardian.com/world/2014/oct/07/-sp-how-to-talk-to-terrorists-isis-al-qaida (accessed 10 May 2015).

Powell, J. (2014b). Talking to Terrorists: How to End Armed Conflicts. London: Bodley Head. 
Roth, R. and Divall, C., eds (2015). From Road to Rail and Back Again: A Century of Transport Competition and Interdependency. Farnham: Ashgate.

Shaw, J. and Docherty, I. (2014). The Transport Debate. Bristol: Policy Press.

Sheller, M. and Urry, J. (2000). The city and the car. International Journal of Urban and Regional Research 24, pp.737-57.

Stampp, K. (1956). The Peculiar Institution: Slavery in the Ante-Bellum South. New York: Vintage Books.

Thane, P. (2009). History and Policy. History Workshop Journal 67, pp.140-45.

Urry, J. (2004). The 'system' of automobility. Theory, Culture and Society 21(4/5), pp.2539.

Vigar, G. (2002). The Politics of Mobility: Transport, the Environment and Public Policy. London: Spon Press.

Wilkinson, R. and Pickett, K. (2009). The Spirit Level: Why More Equal Societies Always Do Better. London: Allen Lane.

\section{Websites:}

Heathrow Airport, Heathrow's history: http://www.heathrowairport.com/about-us/companynews-and-information/company-information/our-history .

History and Policy (a): http://www.historyandpolicy.org/.

History and Policy (b), statement by Frank Field M.P.:

http://www.historyandpolicy.org/about-us/what-we-do.

UK Research Excellence Framework (REF) website: http://www.ref.ac.uk/.

(All accessed 10 May 2015.) 